\title{
EDITORIAL
}

\section{MOON OVER MIAMI}

I see by the channel four eyewitness news where the Reverend Sun Myung Moon has graduated his first class of seminarians, who will now go out to the fifty states to preach the new Moon gospel.

There were precisely fifty graduates. And there is the trouble with the Moon business.

There was no room for the fifty-first scholar. Nor can we imagine the dean saying, "Sorry, chief, all I could come up with this year was forty-three; they'll have to do." Fifty was the symbolic number, and so the seminary produced exactly fifty graduates.

You will perhaps remind me that Jesus rounded up twelve disciples, to signify His commitment to the twelve tribes of old Israel. But it has always been my impression that He collected them as He went along, in more-or-less haphazard fashion; and when the time came to send them forth, the magical number presented itself to His Consciousness, and $\mathrm{He}$ rounded out the dozen, with His fine sense of manifest destiny. (Forgive me, Christologists; I have spent more time with Matthew than with John.)

Nor was Jesus' Twelve a perfect Twelve. His apostolic dozen included Judas.

Much the same thing happened when Ramakrishna, the great preGandhian saint of nineteenth-century India, came to expand his ministry. A wealthy well-wisher brought him twelve perfect orange robes, to confer upon twelve perfect disciples, in keeping with his vision that the religion of the Avatars and the religion of the Incarnation were finally to manifest themselves as one universal faith. Ramakrishna conferred eleven of the robes on eleven faithful and earnest lads, but withheld the twelfth, somewhat mysteriously. The eleven good and true disciples must have been a little shocked when it dawned on them that the twelfth robe was reserved for a fat and prosperous middle-aged drunkard and sensualist named Girish Ghosh, producer of plays in stinking Calcutta, who had caused Ramakrishna endless pain and abuse.

Does the enigmatic Mr. Moon have a wild card in his deck, we wonder? Is there a Judas among those fifty? We hope not, for we wish the new Messiah no ill. And we rather suspect that Jesus knew what He was doing when he added Judas to the pack; just as Ramakrishna knew all about Girish. He included Girish, not despite his unsavory side, but for being the very man he was. The twelfth apostle teaches the world the lesson of love far better than the other eleven can. Perfection is no perfection without its imperfection. Love is life; and there is no life without imperfection. Life, in the end, cannot be pasteurized. The new 
Messiah has produced fifty pasteurized disciples, to save America. But what we must be saved from is our own pasteurization.

But suppose the wild card appears anyhow-as wild cards are apt to do. The Honorable Elijah Muhammad surely did not know about Malcolm X until it was too late; and he seems never to have had the unsettling pleasure of knowing how well his son Wallace would turn out. Originality will out, no matter how hard we try to launder ourselves clean of it. Spontaneity, independence, orneriness-they are like weeds; they give the conscentious gardener no rest.

Just suppose that wild card does exist: where has the Reverend Mr. Moon unwittingly sent him? The Malabar coast of India claims the final resting place for the doubting Thomas; where will this doubting Thomas be deposited? It's anyone's guess, I suppose. But since real estate investment and theology are so intricately interwoven in the Moon web, it amuses us to think he may well turn up in Florida, that archetypal Garden of Eden of the land boom psychology.

We of course urge our readers to watch their own home states, for no one can know for certain. But as for us, we will have one eye on Barrytown, New York, and the other on Disney World.

-ALBERT WILLIAM SADLER 